\title{
A Look Inside Two Central Banks: The European Central Bank and the Federal Reserve
}

\author{
Patricia S. Pollard
}

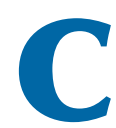
entral banks have existed since the Swedish Riksbank began operation in 1668. The Federal Reserve, which was created in 1913, is thus a relative newcomer in the history of central banking: At the time of its creation, however, only 20 other central banks existed. The number of central banks rose rapidly in the post-World War II period primarily as a result of decolonization. This number expanded again in the early 1990s as the collapse of the Soviet Union led to the establishment of central banks by the former Soviet republics. By 1997 there were 172 central banks. ${ }^{1}$ In 1998 the coterie of central banks expanded by one, when the European Central Bank (ECB) became the newest member.

Central banking has changed greatly since its early history, when the primary function of a central bank was to act as the government's banker. Broz (1998) argues that financing military endeavors was the main reason for the establishment of the early central banks, pointing out that all "central banks in existence before 1850 were chartered in the context of war." 2

By the time the Federal Reserve was established, the role of the central bank had evolved to focus primarily on providing stability in banking and financial systems. At this point, no mention had been made of monetary policy. The Federal Open Market Committee (FOMC), the policymaking group of the Federal Reserve, was not created until 1933. ${ }^{3}$

\footnotetext{
1 See Pringle (2002).

2 Broz (1998, p. 239)

3 In 1923 the Federal Reserve Banks of Boston, Chicago, Cleveland, New York, and Philadelphia established an Open Market Investment Committee to coordinate open market operations conducted by these Reserve Banks. In 1930 this was replaced by the Open Market Policy Conference consisting of the heads of all 12 regional Banks and the members of the Board of Governors. It was not until the 1935 amendment to the Federal Reserve Act that the regional Banks were prohibited from conducting independent open market operations. See Meulendyke (1998) for more details.

Patricia S. Pollard is a research officer at the Federal Reserve Bank of St. Louis. Heidi Beyer provided research assistance.

(1) 2003, The Federal Reserve Bank of St. Louis.
}

Today the primary function of a central bank is, in fact, monetary policy. Moreover, it is widely accepted that a central bank needs to be able to operate independently within the government to best achieve its monetary policy goals. The statutes governing the ECB reflect these shifts and establish monetary policy as the primary function of the ECB, with many other tasks being delegated to the national central banks. The 1993 Maastricht Treaty amendments to the Treaty Establishing the European Community required that not only the $\mathrm{ECB}$, but also the national central banks, be independent. In the 10 years since the Maastricht Treaty was signed, increasing attention has focused on counterbalancing central bank independence with accountability and transparency.

This article examines modern central banking with a focus on the world's two most prominent central banks - the Federal Reserve System and the European Central Bank. ${ }^{4}$ First, it examines the structure and appointment process of the key policymakers at the central banks. Next, it highlights the tasks of the central banks, focusing on the monetary policy process. The goals and tools of monetary policy as well as the decisionmaking process and how they differ in each system are discussed. Finally, the article examines accountability and transparency in the Federal Reserve and the ECB.

\section{STRUCTURE OF THE ECB AND THE FEDERAL RESERVE}

On June 1, 1998, the Executive Board of the ECB held its first meeting at its headquarters in Frankfurt, Germany. Six months later the ECB assumed responsibility for monetary policy in the euro area, bringing to fruition a plan for monetary union first outlined nearly two decades earlier. ${ }^{5}$

\footnotetext{
4 The United States and the euro area account for 37 percent of world output (International Monetary Fund, 2002, Statistical Appendix Table A).

5 See the boxed insert "The Path to Monetary Union."
} 


\section{THE PATH TO MONETARY UNION}

In March 1957, six countries-Belgium, France, Germany, Italy, Luxembourg, and the Netherlandssigned the Treaty of Rome, creating the European Economic Community. The main focus of the treaty was the creation of a customs union among the member countries. ${ }^{1}$ Coordination of monetary and fiscal policies was mentioned by the Treaty as important to the well-functioning of a customs union. The coordination of general economic policies took place through meetings of the Council of Economics and Finance Ministers. In 1964 the Committee of Central Bank Governors was established to coordinate monetary polices in the member states. This was primarily a forum for exchanging information.

In the late 1960s economic and monetary coordination received greater focus, partly in response to the success of the customs union and partly in response to the emerging turbulence in the Bretton Woods fixed exchange rate system. ${ }^{2}$ In 1970 the Council of the European Communities established a committee to discuss economic and monetary union. The group, led by Pierre Werner, the Prime Minister of Luxembourg, issued a report advocating a three-stage movement to economic and monetary union by the end of the decade. Although the Council initially supported the plan, the economic instability resulting from the collapse of the Bretton Woods system and the oil crisis in the early 1970s led to its demise. It was not until 1988 that another committee was established to address the issue of monetary and economic union, this time led by Jacques Delors, the head of the European Commission.

During the 18-year interval, many changes had occurred. The European Community went through three expansions, incorporating six new members. ${ }^{3}$ In 1979 the European Monetary System (EMS) created a fixed exchange rate system in which all member currencies, except the pound sterling, participated. Despite frequent adjustments to the exchange rates in the early years, the success

\footnotetext{
1 A customs union is characterized by free trade among the member countries in conjunction with a common external tariff and common trade policy toward nonmember countries.

2 For a more detailed discussion of the historical development of monetary union in Europe, see Arestis, McCauley, and Sawyer (1999).

3 Denmark, Ireland, and the United Kingdom joined in 1973; Greece in 1981; and Portugal and Spain in 1986.
}

of the EMS in reducing exchange rate variability and the willingness of countries to adopt the economic policies necessary to stabilize exchange rates led to a renewed commitment toward economic and monetary integration. Economic integration was furthered by the passage of the Single European Act in 1987, which called for the creation of a free market in the movement of goods, services, and capital by 1993. The creation of a single European market, it was argued, would be hampered by fluctuations in exchange rates as well as the costs of exchanging currencies.

In April 1989 the Delors committee released its report. Like the Werner report, it called for a three-stage process to achieve economic and monetary union within a decade. ${ }^{4}$ The culmination of the process would be the creation of a supranational institution to set monetary policy and a single currency.

In December 1991, the European Council finalized an agreement on changes to the Treaty of Rome to attain economic and monetary union. ${ }^{5}$ The amendments (often referred to as the Maastricht Treaty, after the Dutch town where the agreement was reached) came into effect in November 1993 following ratification by the member states. ${ }^{6}$

In January 1995, Austria, Finland, and Sweden entered the European Union, bringing the membership to 15. In May 1998, 11 countries (Austria, Belgium, Finland, France, Germany, Ireland, Italy, Luxembourg, the Netherlands, Portugal, and Spain) were certified as having met the membership criteria for admission to monetary union and became members effective January $1,1999 .{ }^{7}$ Greece met the membership criteria in 2000 and became the 12th member in January 2001.

\footnotetext{
4 The Werner report called for greater integration of fiscal policies than did the Delors report. The former envisioned the transfer of national budgetary powers to the European Community (see Wellnik, 1997).

5 The United Kingdom supported the changes only after it was given the right to opt out of monetary union.

6 Denmark rejected the Maastricht Treaty in a referendum. A second referendum passed after Denmark was also given the right to opt out of monetary union

7 Denmark and the United Kingdom exercised their rights to opt out of monetary union. Sweden guaranteed its lack of fitness for membership by failing to join the exchange rate mechanism of the European Monetary System. For a discussion of the membership criteria for monetary union, see Pollard (1995).
} 


\section{Figure 1}

\section{The Federal Reserve System}

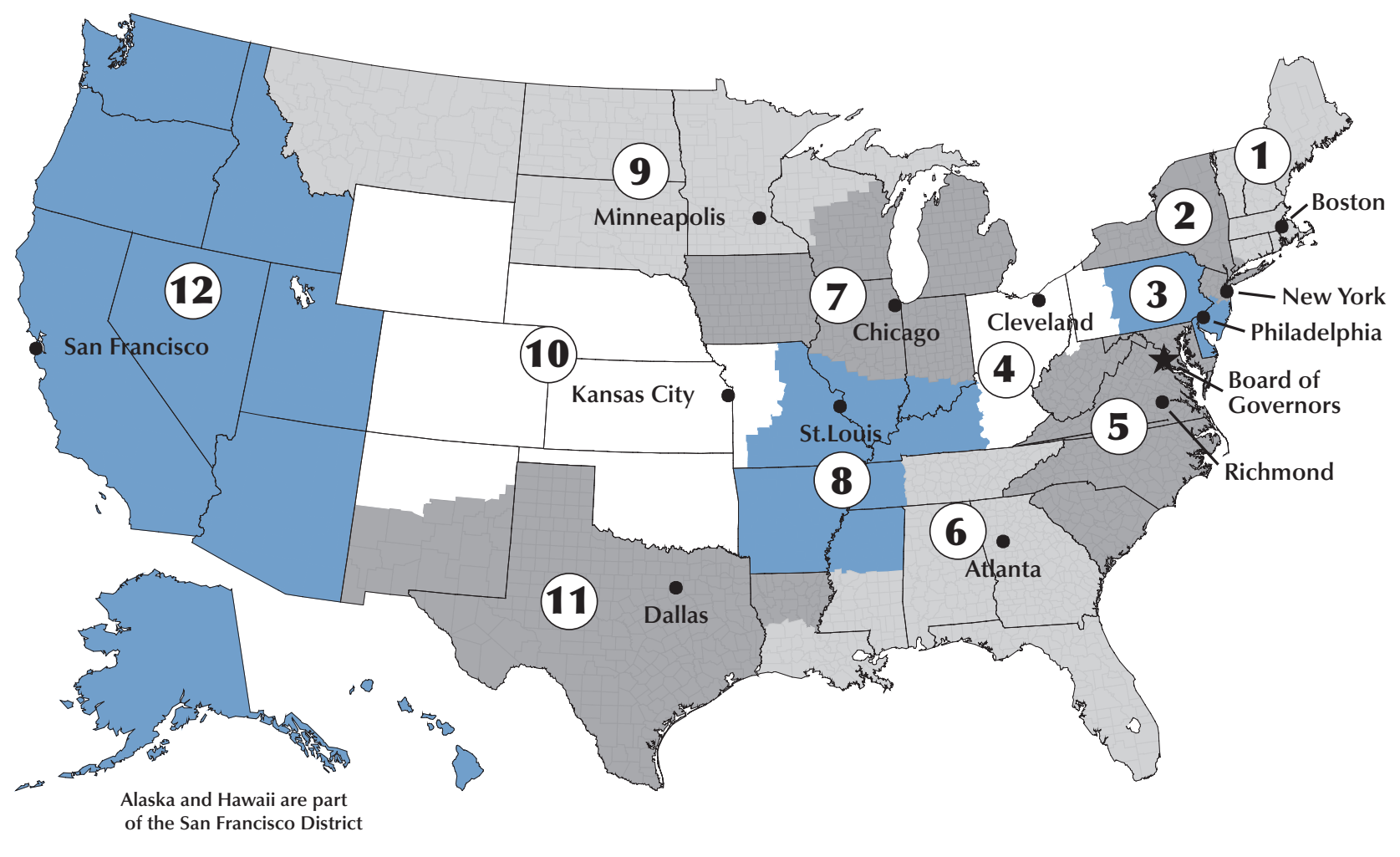

The euro area is unique among commoncurrency areas. Twelve sovereign nations have not only adopted a common currency, the euro, but have also created a supranational organization, the ECB; this institution, along with input from the head of each member country's national central bank, sets monetary policy for the euro area.

Ninety years ago, the Federal Reserve Act created a central bank for the United States consisting of 12 regional (District) Federal Reserve Banks (Figure 1) and a seven-member Federal Reserve Board in Washington, D.C. ${ }^{6}$ In 1935 the Federal Reserve Board was renamed the Board of Governors of the Federal Reserve System.

The European System of Central Banks consists of 15 national central banks (Figure 2) and a sixmember Executive Board in Frankfurt, Germany. The 15 central banks correspond to the 15 member countries of the European Union. The three central banks whose countries are not members of the

\footnotetext{
6 The Federal Reserve Act specified that there be "not less than eight nor more than twelve" Districts (Section 2.1); the text appears at $<$ fedweb.frb.gov/fedweb/board/legal/lawlib/law-fra.htm > .
}

euro area participate in few of the activities of the European System of Central Banks. The Eurosystem is the term used to refer to the ECB and the 12 national central banks of the member countries. ${ }^{7}$

The 12 Districts of the Federal Reserve System, in contrast to the national central banks of the Eurosystem, do not correspond to political entities. These 12 Districts are divided along county lines, encompassing not only multiple states, but portions of states. Indeed, in the early years of the Federal Reserve System, some border counties petitioned and were allowed to switch Districts. ${ }^{8}$

\section{Appointments to the Board of Governors and Executive Board}

The members of the Board of Governors of the Federal Reserve System are nominated by the

\footnotetext{
7 These countries are Austria, Belgium, Finland, France, Germany, Greece, Ireland, Italy, Luxembourg, the Netherlands, Portugal, and Spain. Denmark, Sweden, and the United Kingdom are the three nonmembers.

8 See Federal Reserve Bank of Minneapolis (1988), Hammes (2001), and Primm (1989) for more details on the creation of the 12 Districts.
} 


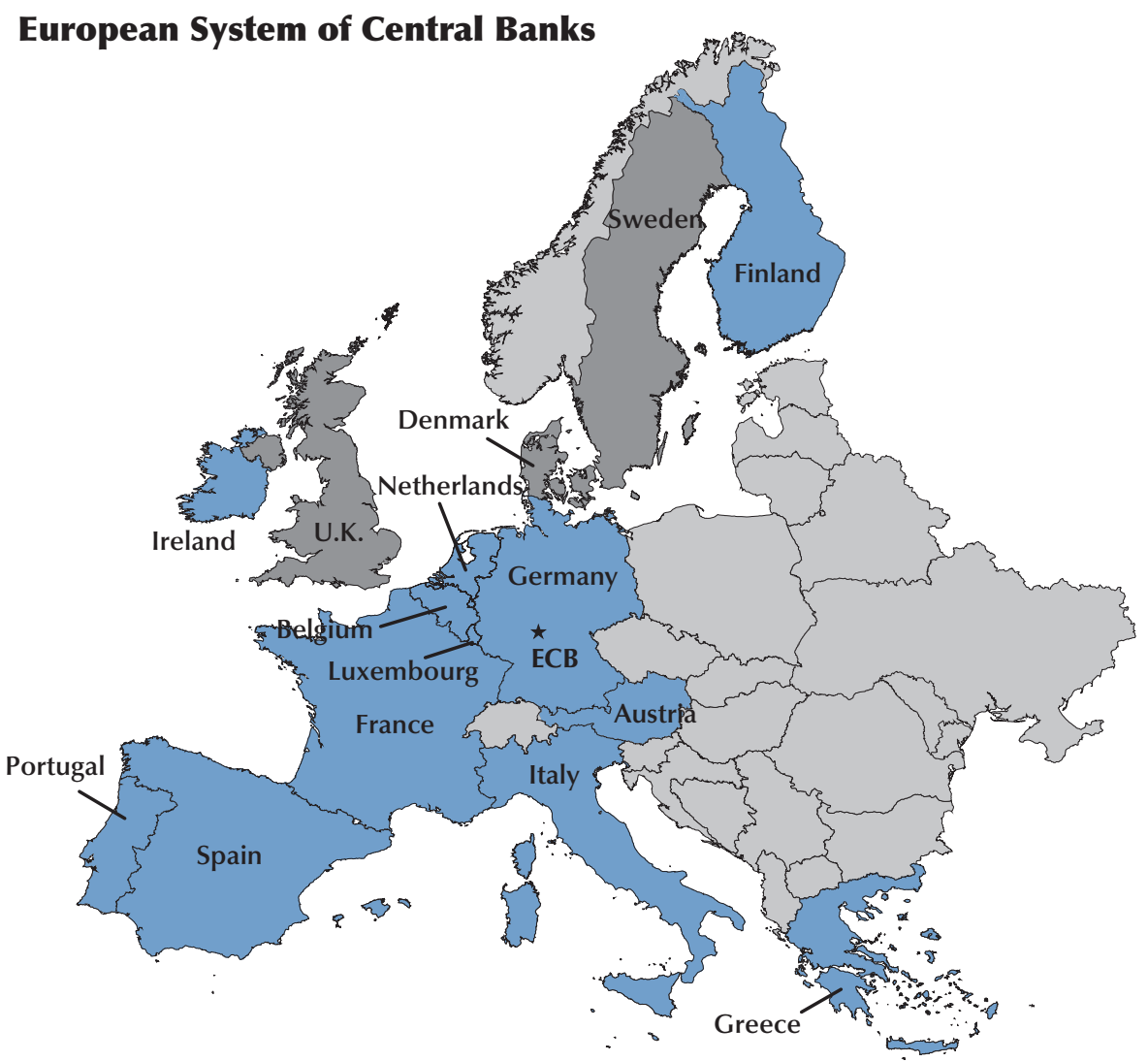

NOTE: Only the central banks of the blue shaded countries are members of the Eurosystem.

President of the United States and must be confirmed by the U.S. Senate. The chairman and vice chairman are appointed by the President and confirmed by the Senate from among the members of the Board, although appointment to these roles may be simultaneous with appointment to the Board.

In Europe the governments of all the member states of the euro area must agree on the appointments to the Executive Board. The process begins with a recommendation by the Council of Economics and Finance Ministers (ECOFIN). ${ }^{9}$ Since ECOFIN comprises the finance ministers of the member countries of the European Union, its recommendations will reflect the consensus of the member governments. Once ECOFIN makes its recommendation, the European Parliament and the Governing

9 See the boxed insert "Institutions of the European Union."
Council of the ECB are consulted. ${ }^{10}$ Following these consultations the appointments are confirmed by the heads of state or government of the euro area members.

The Federal Reserve Act and the Maastricht Treaty both briefly mention qualifications for membership on the respective boards. The Federal Reserve Act specifies that

In selecting the members of the Board, not more than one of whom shall be selected from any one Federal Reserve district, the President shall have due regard to a fair representation of the financial, agricultural, industrial, and commercial interests, and geographical divisions of the country. (Section 10.1)

\footnotetext{
10 The Governing Council consists of the members of the Executive Board and the heads of the 12 central banks in the euro area.
} 


\section{INSTITUTIONS OF THE EUROPEAN UNION1}

Four institutions of the European Union are mentioned throughout the text. They are the European Commission, the Council of the European Union, the European Council, and the European Parliament.

The European Commission is the executive branch of the European Union government. The president of the Commission is nominated by the European Council and approved by the European Parliament. The European Council in consultation with the President of the Commission chooses the other 19 commissioners. The European Parliament must reject or accept the proposed Commission, but may not reject individual members. The appointments to the 20-member commission are based on nationalities. France, Germany, Italy, Spain, and the United Kingdom each are allocated two commissioners with the remaining ten EU countries each allowed one appointment. ${ }^{2}$ All commissioners serve a five-year renewable term. The Commission has four main roles: (i) initiate policies by proposing legislation to the Council and European Parliament; (ii) administer and implement European Union policies; (iii) enforce European Union laws; and (iv) represent the European Union internationally, particularly in negotiations regarding trade and cooperation.

During their term in office the commissioners are expected to represent the interests of the European Union and not those of their home

\footnotetext{
1 Information in this section comes from European Communities (1995-2002) and European Parliament (2001)

2 Under the Treaty of Amsterdam the number of commissioners from any member country will be limited to one, at most, as the European Union expands eastward.
}

countries. In contrast, the Council of the European Union (usually referred to as the Council) represents the national governments. The composition of the Council changes depending upon the issue being considered. For example, the agricultural ministers of the member states address issues related to the Common Agricultural Policy. The Council of Economics and Finance Ministers coordinates the economic policies of the member states.

The Council is the main decisionmaking body of the European Union. Each country is allocated a number of votes based loosely on the size of its population. The Council enacts European Union laws stemming from proposals submitted by the Commission. Most decisions are made by a qualified majority vote, which requires 62 of 87 votes or in some cases 62 votes from at least ten member countries. Some policies such as tax measures and foreign policy require unanimity.

The European Council consists of the heads of state or government of the 15 member countries and the president of the European Commission (as a non-voting member). It is not legally an institution of the European Union but plays a key role. The presidency of the European Council rotates among the member states on a six-month basis. The European Council meets at least twice per year (in June and December). Decisions are generally reached through consensus.

The European Parliament is the other legislative institution of the European Union. Its 626 members are directly elected for five-year terms. Although elected nationally, the members of Parliament are grouped according to party affiliation and not nationality. Although the Parliament shares some legislative powers with the Council, its main purpose is to exercise democratic control over European Union institutions.
The treaty establishing the ECB set no such requirement for regional or national diversity, simply stating that "only nationals of Member States may be members of the Executive Board" (Article 112). ${ }^{11}$ The treaty did set further qualifications for the Board members, stating that they must be "persons of recognized standing and professional experience in monetary or banking matters" (Article 112).

\footnotetext{
${ }^{11}$ The articles listed in the text refer to the Treaty Establishing the European Community as amended by the Treaty of Amsterdam in 1997.
}

In practice, the regional restriction placed by the Federal Reserve Act is loosely applied. For example, the two most recently appointed members, Ben Bernanke and Donald Kohn, represent the Atlanta and Kansas City Districts, respectively. Neither lived nor worked in these Districts at the time of his appointment. What then is the link with the Districts they represent? Bernanke was born in Georgia and Kohn worked at the Federal Reserve Bank of Kansas City in the early 1970s. 
The appointments to the Executive Board of the Eurosystem, however, have thus far been made to ensure national diversity. Indeed, given that there are only half as many positions on this Board as there are current euro area member countries and that the ratio will decline as more countries achieve membership, it is unlikely that there will ever be two Board members appointed from the same country.

Currently, all the members of the Executive Board are experienced central bankers, each having served on the staff of his or her national central bank. ${ }^{12}$ Despite the requirement that the members of the Fed's Board of Governors should reflect a range of interests, in recent years they have been primarily economists and/or bankers. ${ }^{13}$

Term of Office. Members of the Board of Governors are appointed for a 14-year term, nearly twice as long as the eight-year term for members of the Executive Board. Both are nonrenewable. The actual term for a member of the Board of Governors could, however, be much longer: If a member resigns prior to the end of the term of office, the new member is appointed to serve the remainder of the term and then can be appointed to a full 14-year term. ${ }^{14}$ Alan Greenspan, for example, was appointed in 1987 to fill the remaining years of Paul Volcker's term and was reappointed in 1992 to a 14-year term.

The chairman and vice chairman of the Board of Governors serve four-year terms that may be renewed as long as their terms on the Board have not expired. Renewal requires nomination by the President of the United States and the consent of the U.S. Senate. On the Executive Board, the president and vice president are appointed for the full eightyear nonrenewable term.

The terms of members on both Boards are staggered to provide continuity. ${ }^{15}$ In the United States, however, few members now serve the full 14 years and the appointment process is sometimes slow, so multiple vacancies may occur. All members of the current Board of Governors, with the exception

\footnotetext{
12 Brief biographies of the members of the Executive Board are available at <www.ecb.int/about/ab1 mem.htm >

13 Brief biographies of the members of the Board of Governors are available at <www.federalreserve.gov/bios $>$

14 Since the 1935 amendment to the Federal Reserve Act restricted future appointees to the Board of Governors to one full term, the longest anyone has served is 21 years.

${ }^{15}$ To achieve this in the ECB, the terms of office were set at two to eight years for the initial Executive Board members.
}

of the Chairman, were appointed within the last five years, and four members were appointed in the last two years. Figures 3 and 4 show the current members of the Board of Governors and the Executive Board, respectively, along with the District or country they represent and the expiration date of their terms.

\section{Appointments of the District Bank Presidents and the Governors of the National Central Banks}

The president of a Federal Reserve Bank is appointed by the board of directors of that Bank, subject to the approval of the Board of Governors. The term of office of all the presidents expires on the same date, the last day of February in years ending with a 1 or 6 . The president may be reappointed for an indefinite number of five-year terms, subject to the following restrictions: mandatory retirement at age 65 if appointed at or before age 55 or mandatory retirement at age 70 or a 10-year term (whichever comes first) if appointed after age 55. ${ }^{16}$ There is no requirement that the president be a resident of the District prior to appointment.

The appointment of the governor of each national central bank in the euro area is determined by the respective national government. The Maastricht Treaty requires that the term of office be a minimum of five years. The term varies across countries from five to eight years. ${ }^{17}$ Eight of the 12 countries allow for a renewable term. The Executive Board need not be consulted and has no veto power over these appointments.

\section{Tasks of the Central Banks}

Apart from conducting monetary policy, central banks have a variety of other tasks. These other duties are often related to the monetary policy function. In general the duties of the Federal Reserve and the Eurosystem (listed in Table 1) are similar, yet there are some key differences. ${ }^{18}$

Both central banks are the sole issuer of banknotes for their respective economies. In the euro area, production and distribution is controlled by

\footnotetext{
${ }^{16}$ No such age restriction applies to members of the Board of Governors. Alan Greenspan, for example, will be 78 when his current term as Chairman expires in 2004

17 The term is five years in Austria, Belgium, Italy, and Portugal; six years in France, Greece, Luxembourg, and Spain; seven years in Finland, Ireland, and the Netherlands; and eight years in Germany.

18 See Board of Governors (1994) for a more detailed description of the tasks of the Federal Reserve System.
} 


\section{Figure 3}

\section{Members of the Board of Governors}

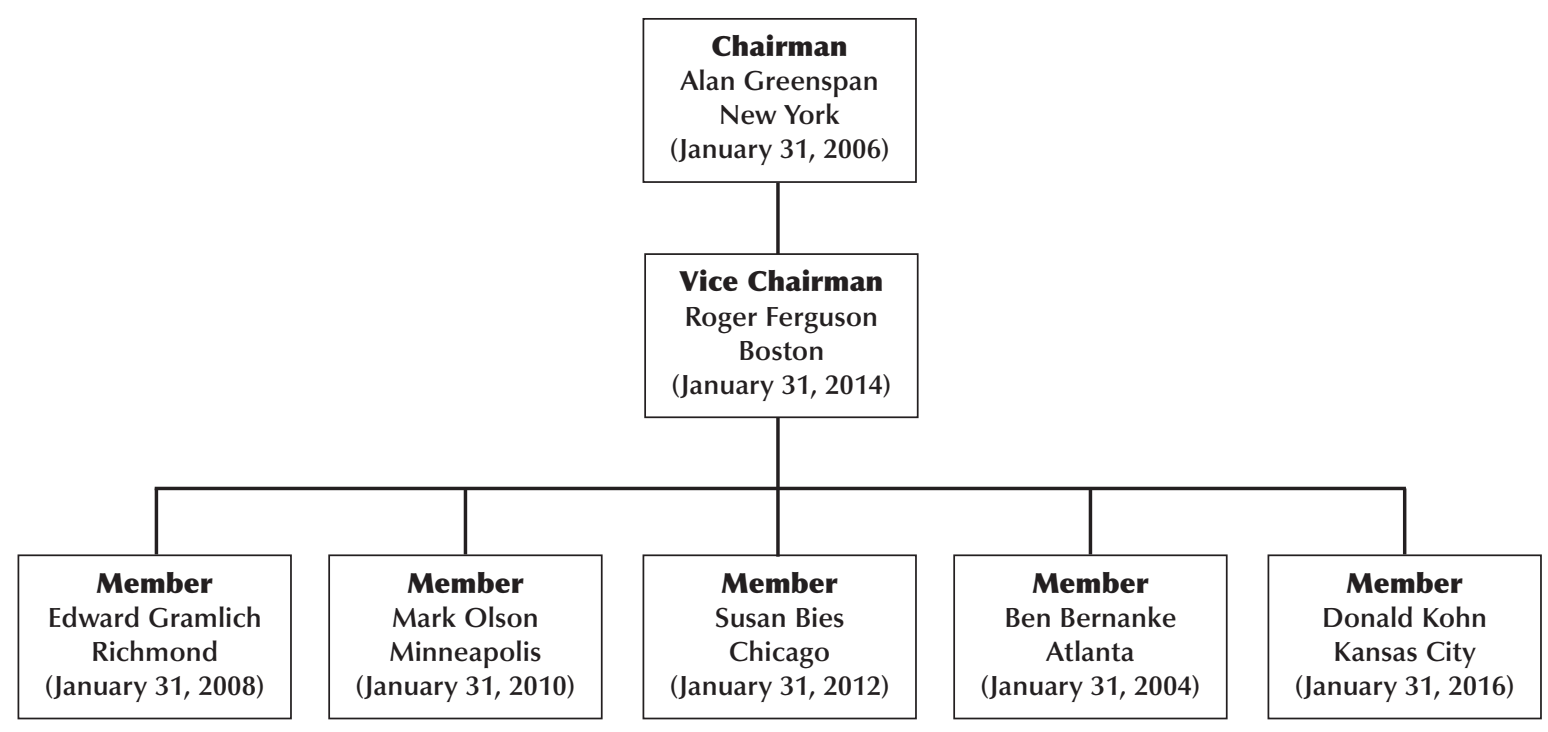

NOTE: Date indicates expiration of term.

\section{Figure 4}

\section{Members of the Executive Board}

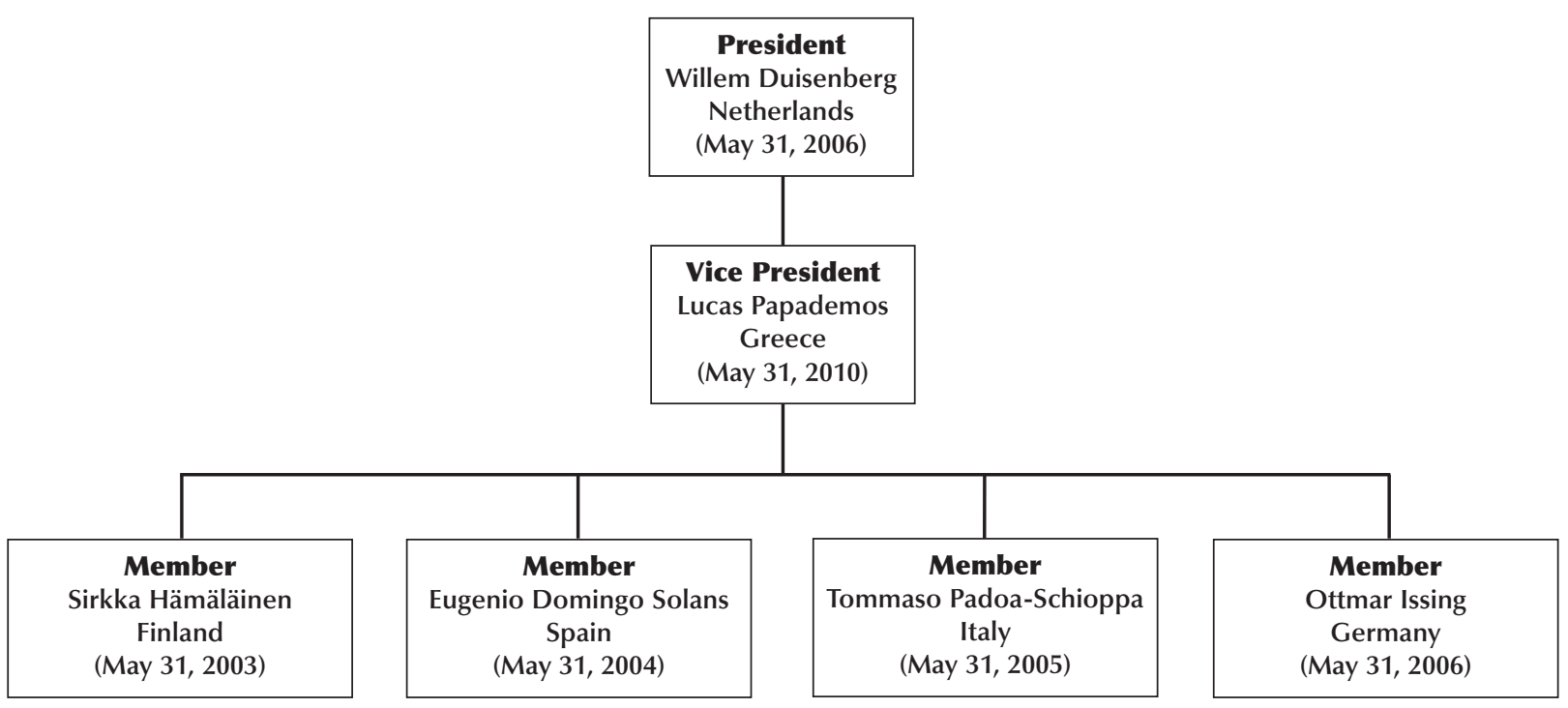

NOTE: Date indicates expiration of term. 


\section{Table 1}

\section{Tasks of the Federal Reserve System and European System of Central Banks}

\begin{tabular}{llc} 
& FRS & ESCB \\
\hline Define and implement monetary policy & Yes & Yes \\
Issue banknotes & Yes & Yes \\
Conduct foreign exchange operations & Yes & Yes \\
Hold and manage official reserves & Yes & Yes \\
Act as the fiscal agent for the government & Yes & Yes \\
Promote stability of financial system & Yes & Some NCBS \\
Supervise and regulate banks & Yes Some NCBS \\
Implement consumer protection laws & Yes & Yes \\
Promote the smooth operation of the payments system & Yes & Yes \\
Collect statistical information & Yes
\end{tabular}

NOTE: NCBS refers to national central banks of the Eurosystem.

the ECB with production occurring in all 12 member countries. In the United States, Federal Reserve notes are produced by the Bureau of Engraving and Printing (part of the U.S. Treasury Department) under the direction of the Board of Governors. Federal Reserve notes are then purchased at cost, not face value, by the Federal Reserve Banks. Production takes place in only two locations-Fort Worth, Texas, and Washington, D.C.

Neither the ECB nor the Federal Reserve is responsible for exchange rate policy (for example, deciding whether to enter into a fixed exchange rate arrangement). This responsibility lies with ECOFIN in the euro area and the Treasury Department in the United States. ECOFIN is required, however, to consult the ECB before entering into any exchange rate arrangements and must not allow such arrangements to take precedence over the ECB's price stability objective (Article 111). Both central banks, however, may intervene in foreign exchange markets and may hold and manage foreign currency reserves.

Both central banks provide financial services to the government. These tasks are primarily handled by one of the Reserve Banks in the United States, currently the Federal Reserve Bank of St. Louis. In the euro area each national central bank serves as fiscal agent for its own government. There are limitations placed on the fiscal agency function of both central banks to prevent the government from using this relationship to finance budget deficits. For example, both the Federal Reserve and the European
System of Central Banks are prohibited from extending loans to the government or from directly purchasing securities from the government.

Because of the key role the financial system plays in the economy, maintaining the stability of the financial system is an important objective of both central banks. The Federal Reserve plays a role in supervising and regulating banks to this end. It shares supervisory tasks with three federal agencies and with state agencies. In addition the Federal Reserve shares tasks with foreign agencies in supervising U.S. banks with branches abroad and foreign bank branches in the United States.

The Federal Reserve serves as a bank regulator in setting standards regarding the operations and activities of banks. As a complement to this regulation, the Federal Reserve implements consumer protection laws in the area of credit and financial transactions.

The European System of Central Banks has no direct role in banking supervision. The Maastricht Treaty simply states that it

shall contribute to the smooth conduct of policies pursued by the competent authorities relating to the prudential supervision of credit institutions. (Article 105)

Responsibility for supervision in the euro area is determined nationally. Although most national central banks have some role in supervision, several 
countries have followed or are considering following the lead of the United Kingdom in removing supervision from the functions of the central bank. The ECB has argued for expanding the supervisory role of the national central banks, as well as increasing cooperation among those banks (ECB, 2001b). ${ }^{19}$ In April 2001 the European System of Central Banks reached an agreement with the banking supervisory authorities in the European Union countries to increase cooperation. 20

An important task related to supervision is the role of the central bank as a lender of last resort. The Federal Reserve can use the discount window (discussed here later) to make loans to banks that are, although solvent, temporarily illiquid. The Maastricht Treaty does not mention a lender of last resort function for the ECB, and the ECB has been criticized for lacking this function. ${ }^{21}$ Perhaps as a result of this criticism, although it remains silent about the specifics, the ECB has reiterated that it has the ability and the willingness to handle a liquidity crisis in the euro area banking system. Willem Duisenberg, president of the ECB, said the following in response to a question regarding the role of the $\mathrm{ECB}$ as a lender of last resort: "The Governing Council has this issue well under control but will never make anything public in this regard" (Duisenberg, 1998). Tommaso Padoa-Schioppa, a member of the Executive Board, stated that

To the extent that there would be an overall liquidity effect that is relevant for monetary policy or a financial stability implication for the euro area, the Eurosystem itself would be actively involved. (Padoa-Schioppa, 1999)

Financial regulation and consumer protection in credit and financial matters generally remains at the national level in the Eurosystem, although the European Union is looking at ways to establish regulations both to promote financial integration and handle the regulatory complications resulting from such integration.

The role of the central bank in overseeing the payments system is linked to both its role in ensuring the stability of the financial system and its conduct of monetary policy. The Protocol on the Statute

\footnotetext{
${ }^{19}$ This document provides an overview of the debate regarding the role of central banks in banking supervision.

${ }^{20}$ See ECB (2001a).

${ }^{21}$ See, for example, Bordo and Jonung (1999) and Prati and Schinasi (1998).
}

of the European System of Central Banks and of the European Central Bank permits the ECB and the national central banks operational roles in the payments system and gives the ECB the authority to make regulations to "ensure efficient and sound clearing and payment systems" (Article 22). National central banks also provide oversight for payment and clearing systems operated by private entities. In preparation for monetary union, domestic payments systems were required to meet minimum standards. The ECB operates TARGET, a real-time gross settlement system to aid in central bank operations and the settlement of cross-border and largevalue euro payments in the euro area. ${ }^{22}$ The Federal Reserve both operates clearing and payments systems and oversees those operated by private entities.

Both central banks cooperate internationally, generally through the Bank for International Settlements, in working to minimize the risk of problems arising in cross-border payments. International cooperation extends to other areas of central banking, particularly in issues related to financial stability and monetary policy. Central bankers from the ECB and the Federal Reserve participate in meetings of the international monetary institutions as well as less formal forums for discussion.

Both central banks collect and publish data related to banking and monetary aggregates, as well as other indicators of economic activity. These data are particularly useful in the central banks' task of implementing monetary policy. Interestingly, neither central bank collects the data used to measure inflation. These data are constructed by the Bureau of Labor Statistics in the United States and Eurostat in the European Union.

\section{MONETARY POLICY}

The main function of both the Federal Reserve and the ECB is to conduct monetary policy to achieve the goals assigned by their respective charters. This section begins with a discussion of these goals, followed by an analysis of the tools available to the two central banks in conducting monetary policy. It then turns to the monetary policy decision process, looking at both the differences in the decisionmaking bodies in the United States and the euro area and the process by which decisions are made.

\footnotetext{
${ }^{22}$ For more details on payment and clearing systems in the euro area, see ECB (2001b).
} 


\section{Figure 5}

\section{Federal Funds Target and Effective Rate}

January 1, 1999, to September 20, 2002

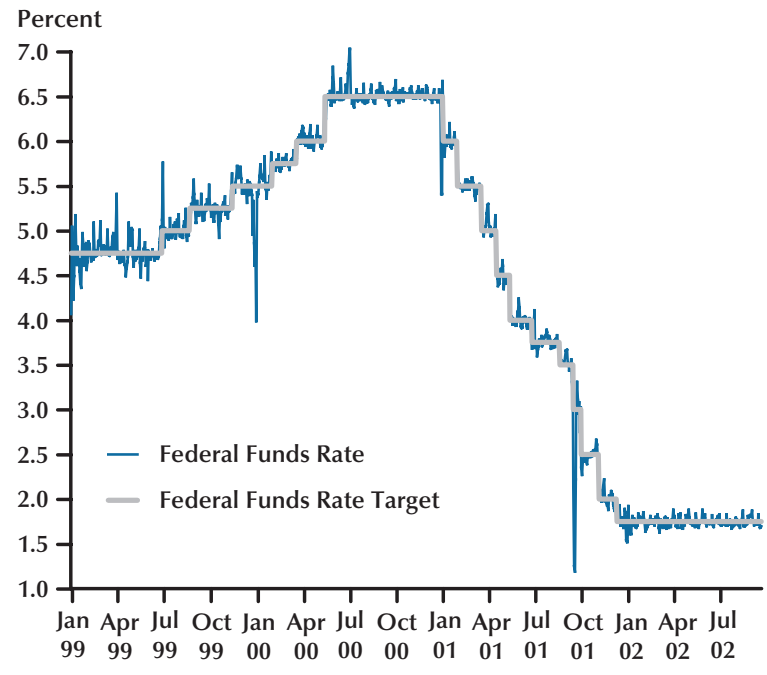

\section{Monetary Policy Goals}

The primary goal of the Eurosystem as set forth by the Maastricht Treaty is to "maintain price stability" (Article 105.1). The treaty further instructs the Eurosystem to "support the general economic policies" (Article 105.1) in the euro area without prejudice to the goal of price stability. Thus, the treaty makes it clear that any other objectives are secondary to that of price stability.

The ECB has given a quantitative definition to its mandate of price stability. Price stability is "a year-on-year increase in consumer prices of below $2 \%$ " (ECB, 2001c) as measured by the monetary union index of consumer prices for the euro area. 23 Because prices are affected in the short-run by many factors outside the control of the central bank and because monetary policy actions take time to affect inflation, the objective is seen as applying over the medium term.

The Federal Reserve System has three policy goals: "maximum employment, stable prices and

23 The monetary union index of consumer prices is a weighted average of the harmonized indexes of consumer prices for the euro area countries. The weights are based on each country's share of euro area private domestic consumption expenditures. The harmonized indexes of consumer prices cover the same set of goods and services in each country and are calculated using the same methodology. The weights given to each item within the index, however, vary across countries based on the expenditure habits of the country's consumers.

\section{Table 2}

\section{Tools of Monetary Policy}

\begin{tabular}{ll} 
Federal Reserve & ECB \\
\hline Open market operations & Open market operations \\
Discount window & Standing facilities \\
Reserve requirements & Reserve requirements
\end{tabular}

moderate long-term interest rates" (Section 2A). ${ }^{24}$ Unlike the Eurosystem's mandate, price stability is not given a higher priority than the other goals. Clearly, the policymakers of the Federal Reserve must assign at least an implicit ranking to these goals; in the long-run all three goals are compatible, but this is not necessarily true at every point in time. Perhaps as a result of this incompatibility, the Federal Reserve has never defined any of the goals. ${ }^{25}$ Alan Greenspan has given what he termed "an operating definition of price stability": "Price stability obtains when economic agents no longer take account of the prospective change in the general price level in their economic decisionmaking" (Greenspan 1996).

\section{Monetary Policy Tools}

The tools available to the two central banks are listed in Table $2 .{ }^{26}$ In its policy meetings, the Federal Reserve sets a target for the federal funds rate, the interest rate banks charge each other to borrow reserves overnight. The Federal Reserve does not directly determine this interest rate but can control it through open market operations, which directly affect bank reserves. The Federal Reserve conducts

\footnotetext{
24 The 1913 Federal Reserve Act did not contain any macroeconomic goals. The 1946 Employment Act required the federal government to "promote maximum employment, production and purchasing power." Although the act did not mention the Federal Reserve, it was interpreted as applying to it. The 1977 Federal Reserve Reform Act specified the three goals listed in the text. See Judd and Rudebusch (1999) for a discussion of the goals of U.S. monetary policy.

25 The 1978 Full Employment and Balanced Growth Act (commonly known as the Humphrey-Hawkins Act) specified goals of 3 percent for inflation and 4 percent for unemployment to be reached by 1983 . The President was required to report in the Economic Report of the President the progress in meeting these goals. If the goals could not be met, the President was required to set revised goals. The Federal Reserve was required to report to Congress twice per year on its own objectives and how these related to the administration's goals. In practice, the Federal Reserve compared its forecasts for growth, unemployment, and inflation over the next two years with those of the administration.

26 See Board of Governors (1994, Chap. 3) and ECB (2002) for a more detailed description of the monetary policy tools.
} 
open market operations by buying or selling U.S. government securities (typically Treasury bills). Generally, open market operations are conducted as repurchase agreements. For example, the Federal Reserve sells securities with an agreement to repurchase them at a later date, usually no more than seven days later. The open market desk at the Federal Reserve Bank of New York is active daily in the market. As Figure 5 shows, through open market operations the Federal Reserve manages to keep the federal funds rate close to its target rate. ${ }^{27}$

Open market operations conducted by the ECB are similar in some respects to those of the Federal Reserve. The ECB's most common open market operations, that is, main refinancing operations, are repurchase agreements that have a maturity of two weeks. There are, however, a few key differences between the use of open market operations by the Federal Reserve and the ECB. The ECB conducts main refinancing operations only once per week in contrast to the Fed's daily operations. Secondly, the Federal Reserve deals exclusively in U.S. government securities, whereas the ECB has a broader range of assets (even beyond that of securities issued by member country governments) that it accepts. Another difference is that, in the euro area, open market operations are decentralized; each national central bank executes operations with the financial institutions in its area, although these operations are coordinated by the ECB.

The main difference in the tools used by the two central banks is in the system of overnight loans made to financial institutions. These are referred to as discount window loans by the Federal Reserve and the marginal lending facility by the ECB. ${ }^{28}$ In the United States, the board of directors of each Fed Bank sets the discount rate (the interest rate it charges on overnight loans to financial institutions) subject to approval of the Board of Governors. ${ }^{29}$

\footnotetext{
27 Two major exceptions have occurred in the last few years. The first was at the end of December 1999, when, as a Y2K precaution, the Federal Reserve allowed the federal funds rate to fall to ensure adequate liquidity for banks. The second was in the aftermath of September 11 , 2001, when again the Federal Reserve allowed the federal funds rate to fall sharply to provide liquidity to banks.

28 The discount window discussed in the text refers to the provision of adjustment credit, that is, credit extended to meet short-term liquidity needs of financial institutions. The regional banks also make discount window loans for seasonal and extended credit, at rates above the discount rate for adjustment credit. Extended credit is used in conjunction with the Federal Reserve's lender-of-last-resort function.

29 Originally discount rates varied across Districts. But with the emergence of a national credit market, the Federal Reserve maintains a uniform discount rate.
}

Figure 6

\section{ECB Key Interest Rates and the Euro Overnight Index Average Rate (EOINA)}

January 1, 1999, to September 20, 2002

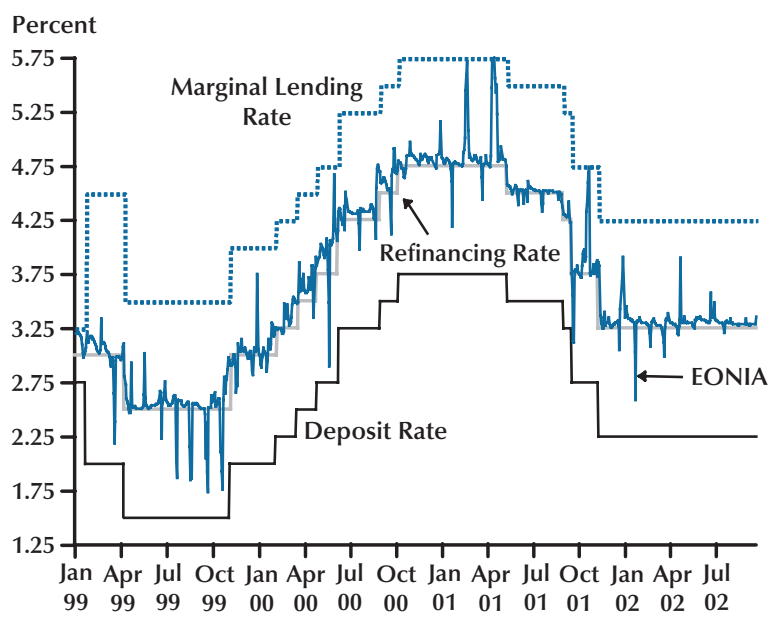

The discount rate is set below the federal funds rate target, yet very little borrowing occurs. 30 This is because the Federal Reserve discourages borrowing at the discount window. ${ }^{31}$

The marginal lending facility operated by the ECB also provides overnight loans to financial institutions. The marginal lending rate is the rate at which financial institutions may borrow from the national central banks. It is set by the Governing Council and is always above the main refinancing rate. ${ }^{32}$ In contrast to the constraints of the discount window, banks are allowed to freely borrow from this facility. ${ }^{33}$

The ECB operates another standing facility in addition to the marginal lending facility. The deposit facility allows banks to deposit funds overnight at the national central banks and earn interest on these deposits. These deposits are beyond those required to meet the minimum reserve requirement, discussed here later. The Federal Reserve also allows

\footnotetext{
30 In recent years the policy has been to set the discount rate 50 basis points below the federal funds rate target.

31 An exception occurred on September 11, 2001, when the Federal Reserve encouraged use of the discount window following disruptions in the federal funds market.

32 The marginal lending rate most often has been set at 100 basis points above the main refinancing rate.

33 Banks must have adequate collateral to borrow, as is also required for discount window loans.
} 
banks to deposit excess reserves at the District Banks but does not pay interest on these reserves. The ECB deposit rate is set below the marginal refinancing rate, and typically the two standing facility rates form a symmetric band around the main refinancing rate, as shown in Figure 6.

More importantly, because banks are allowed to freely deposit and borrow through the standing facilities, the deposit rate and the marginal lending rate form a band around the euro overnight index average rate (EOINA), the overnight interbank rate. No bank will borrow money from another bank if it can borrow at a lower interest rate from the ECB, so the marginal lending rate sets the upper bound for EOINA. No bank will lend money at a lower interest rate than it can get by depositing money at the ECB, so the deposit rate sets the lower bound for EOINA, as shown in Figure 6.

The Federal Reserve has proposed changing the discount window by setting the discount rate 100 basis points above the federal funds rate target and not restricting borrowing. ${ }^{34}$ This would discourage borrowing through a pricing mechanism rather than through the current administrative process. At the same time, the discount window would provide a source of funds when the money market tightens, raising the federal funds rate above its target. The discount rate would also act as a ceiling on the federal funds rate. The proposed changes would make the discount window function similar to the ECB's marginal lending rate.

The Federal Reserve has expressed its support for paying interest on overnight deposits. ${ }^{35}$ Although several bills have been introduced in Congress in recent years to permit this, none have been passed.

Both central banks have established minimum reserve requirements for financial institutions. These are not now used as an active policy tool, as adjustments are infrequent. The Maastricht Treaty gave the Governing Council the right but not the obligation to set reserve requirements. The Federal Reserve Act, as amended by the 1980 Depository Institutions Deregulation and Monetary Control Act, requires the Federal Reserve to impose minimum reserve requirements on all depository institutions. The 1980 amendments also established the ranges for these requirements. The Federal Reserve may, however, temporarily suspend the reserve requirements (Section 11C).

\footnotetext{
34 See Madigan and Nelson (2002)

${ }^{35}$ See, for example, Meyer (2001).
}

\section{Making Monetary Policy Decisions}

Monetary policy decisions for the United States and the euro area are made by the FOMC of the Federal Reserve and the Governing Council of the $\mathrm{ECB}$, respectively. The FOMC consists of the seven members of the Board of Governors, the president of the Federal Reserve Bank of New York, and four other District Bank presidents who serve on a rotating basis. ${ }^{36}$ Each District is grouped with one or two others as follows: Boston, Philadelphia, and Richmond; Cleveland and Chicago; Atlanta, Dallas, and St. Louis; and, Minneapolis, Kansas City, and San Francisco. The presidents of all 12 District Banks attend and participate in the policy deliberations of the FOMC, but only the members of the Board and the five presidents may vote on policy actions. The membership of the Governing Council of the ECB is much simpler, consisting of the six members of the Executive Board and all 12 euro area governors.

By law the Governing Council is required to meet at least ten times per year while the FOMC is required to meet only four times per year. Since its inception the Governing Council has generally met twice per month. This is far more than the FOMC, which since 1981 has scheduled eight meetings per year. Perhaps as a result, the FOMC has more often added meetings (generally through teleconferencing) to react to economic factors that have arisen during the intermeeting period. For example, the FOMC held three such meetings during 2001 (although these were the first since October 15,1999$)$. The only time the Governing Council has added a meeting was on September 17, 2001, to join the Federal Reserve in cutting interest rates as U.S. stock markets reopened following the September 11, 2001, terrorist attacks.

If eight meetings per year may sometimes be too few, 24 meetings per year may be too many. In November 2001, the Governing Council decided to generally limit its monetary policy discussions to

\footnotetext{
${ }^{36}$ When the FOMC was created by a 1933 amendment to the Federal Reserve Act, it consisted of "as many members as there are Federal reserve districts" (Section 12A). The board of directors of each Reserve Bank selected the representative from that District. Members of the Board of Governors were permitted to attend the meetings. In 1935 membership was changed to include "the members of the Board of Governors of the Federal Reserve System and five representatives of the Federal Reserve banks" (Section 12A). In 1942, New York was given a permanent position on the FOMC and the current groupings for the other Districts were established. In addition, the representative chosen by the board of directors of each District Bank had to be either the president or vice president of the Bank (BOG, 2000).
} 


\section{Table 3}

\section{Typical Attendees at a Meeting of the FOMC and the Governing Council}

\section{FOMC}

12 members of FOMC

7 other District Bank presidents

12 District research directors

Secretary of the FOMC

Deputy Secretary of the FOMC

2 assistant secretaries

Manager of System Open Market Account

Director of Research and Statistics, Board of Governors

Director of the Division of International Finance, Board of Governors

Director of Monetary Affairs, Board of Governors

General Counsel

Deputy General Counsel

Other Board staff

SOURCE: Minutes of the FOMC and Haring and Barber (2002).

\section{Governing Council}

18 members of the Governing Council

Translators

Minute taker

European Commissioner for Monetary Affairs, possibly

Chair of the euro area finance ministers, possibly the first meeting of each month. As explained by Duisenberg (2001):

We have the impression that the bi-monthly meetings of the Governing Council also lead, every two weeks, to speculation in the markets and higher volatility in exchange rates and market interest rates than would be the case if we had a calmer rhythm of meetings.

The second monthly meeting is still held but now focuses on issues related to the other tasks of the ECB.

Preparing for Policy Meetings. Generally on the Thursday preceding a Tuesday FOMC meeting, members of the FOMC and the other District Bank presidents receive the Greenbook, a report on the state of the economy prepared by the Board of Governors staff and named for the color of its cover. The Greenbook contains the Board staff's analysis of current economic conditions as well as a forecast of the economy. ${ }^{37}$ A few days later the Bluebook arrives. This report, also prepared by the Board staff and also named after the color of its

\footnotetext{
37 District Bank presidents are also briefed by their staff economists prior to meetings of the FOMC. Only limited numbers of the District staff are allowed to see the reports prepared by the staff at the Board of Governors.
}

cover, summarizes conditions in financial markets and lists the policy options. Two or three options are given, one of which is always to make no change in policy. ${ }^{38}$

About two days prior to the Thursday monetary policy meeting, members of the Governing Council receive a copy of the Orangebook (again, named for the color of its cover), prepared by the ECB's chief economist (currently Ottmar Issing), who is also a member of the Executive Board. ${ }^{39}$ The Orangebook, like the Greenbook, provides an analysis of economic and monetary conditions. In contrast to the Bluebook, it provides not a range of policy options, but a policy recommendation.

The Policy Meeting. ${ }^{40}$ The meetings of the Governing Council are more informal than those of the FOMC, with fewer attendees and fewer formal presentations. Table 3 lists the attendees at a typical meeting of the two policymaking boards. With the

38 A detailed discussion of the FOMC meeting is given by Meyer (1998). Poole (1999) and Nash (2002) also provide insights into the workings of the FOMC.

39 Information on the meetings of the Governing Council is from Haring and Barber (2002).

${ }^{40}$ The proceedings of a monetary policy meeting, particularly with respect to the policy discussion, often reflect the style of the head of the central bank. 
exception of translators, there are normally no more than 21 attendees at the meetings of the Governing Council. ${ }^{41}$ The meetings of the FOMC typically have between 50 and 60 attendees.

Monetary policy meetings of the Governing Council open with a presentation by the ECB's chief economist on the economic outlook report from the Orangebook. The other members of the Governing Council then present their views on policy. The ECB president summarizes the discussion and attempts to form a consensus on policy. No formal vote is taken at the meeting.

Meetings of the FOMC begin with a presentation by the Manager of the System Open Market Account at the Federal Reserve Bank of New York, who discusses open market operations undertaken during the intermeeting period as well as developments in domestic financial markets and foreign exchange markets. ${ }^{42}$ Next, the director of Research and Statistics and the director of the Division of International Finance at the Board of Governors discuss the Board staff's forecast and international develop ments, respectively. Following these presentations, the Reserve Bank presidents and the members of the Board of Governors provide their own assessment of economic conditions and the outlook. The next part of the meeting focuses on a discussion of policy. The director of Monetary Affairs at the Board outlines the policy options given in the Bluebook. The Chairman then presents his policy preference. This is followed by an open discussion by members of the FOMC and the other District Bank presidents. At the close of this discussion the Chairman summarizes the discussion. He then reads a policy directive that reflects the view of the committee. The members of the FOMC vote on the policy directive.

\section{INDEPENDENCE, ACCOUNTABILITY, AND TRANSPARENCY}

In establishing the European System of Central Banks, policymakers endowed it with a high degree of independence from the governments of the member states and the European Union. The Governing Council, for example, was given explicit control over the tools of monetary policy and is prohibited from taking advice from the governments of the euro area. Even the nonrenewable term of office of

\footnotetext{
${ }^{41}$ According to Haring and Barber (2002), although translators are available, English is the common language of the Governing Council meetings.

${ }^{42}$ Information in this section comes from Meyer (1998).
}

members of the Executive Board was designed to protect them from political interference. ${ }^{43}$ The Maastricht Treaty not only guaranteed the independence of the ECB, but also required that the national central banks be independent as a prerequisite for joining the Eurosystem.

This emphasis on independence was supported by various studies in the late 1980s and early 1990s that showed a negative correlation between the degree of independence of the central bank and the country's inflation rate. ${ }^{44}$ Moreover, studies showed that a country did not have to sacrifice growth to achieve a lower rate of inflation. These studies helped fuel changes in the legal status of many central banks, reducing the amount of direct government control and increasing the emphasis on price stability. When the Federal Reserve Act was passed in 1913, independence of monetary policy was less of a concern: The Secretary of the Treasury as well as the Comptroller of the Currency were members of the Federal Reserve Board, and the former was the Chairman of the Board. Over time, however, the independence of the Federal Reserve has increased. Congress eliminated the two government positions on the Board effective in 1936. ${ }^{45}$ The length of the term of office for Board members was increased from the original 10 years to 12 years in 1933 and then to the current 14 years in 1935. A key step in increasing the independence of the Federal Reserve was the 1951 Federal Reserve-Treasury Accord that released the Federal Reserve from a requirement, begun during World War II, to maintain interest rate ceilings on Treasury securities. This accord is seen as establishing the independence of monetary policy.

Independence, however, is not without its drawbacks. The decisions made by central bankers can have a profound effect on the economy and hence the public. Central bank independence removes these decisions from the hands of elected officials and restricts the ability of the government to remove

\footnotetext{
43 The appointment process, however, has not been without political meddling. When the selections for the initial Executive Board were being made, there was a general agreement among the member governments to appoint Duisenberg as president of the ECB. France, however, insisted that its own candidate, Jean Claude Trichet, be appointed president. France agreed to support Duisenberg only after he agreed to resign part way through his term. On February 7, 2002, Duisenberg announced that he would resign on July 9, 2003, after serving slightly more than five years of his eight-year term.

44 See Pollard (1993) for a review of this literature

45 The 1935 amendment to the Federal Reserve Act that made this change also changed the name of the Federal Reserve Board to the Board of Governors of the Federal Reserve System.
} 
central bank officials. Thus, in democratic societies accountability and transparency are seen as necessary to counterbalance central bank independence. Accountability holds the central bank responsible for its actions. Transparency, the ease with which policy actions can be observed and understood, is necessary for accountability. As explained by Roger Ferguson (2001), the vice chairman of the Board of Governors, transparency "gives the public the tools to hold the independent central bank accountable."

\section{Accountability}

For what should the central bank be accountable and to whom should it be accountable? The central bank should be held accountable for its legislative mandate-specifically, the goals set by the government. ${ }^{46}$ Recall that the goal of the ECB is price stability - specifically, as defined by the Governing Council, an inflation rate of less than 2 percent over the medium term. The goals of the Federal Reserve are maximum employment, stable prices, and moderate interest rates. Accountability is easier when the central bank has a single goal, or at least a ranking of goals; for, as explained by Meyer (2000), multiple goals "always carry trade-offs, at least in the short-run, which are subject to the discretion of the central bank." The precision of numerical goals also aids in accountability. ${ }^{47}$

Ultimately a central bank should be accountable to the public; but, since the public has no direct control over the central bank, it is the obligation of the elected representatives of the people to hold the central bank accountable for its mandate. In the United States, it is natural that the Federal Reserve be accountable to Congress. Not only are the members of Congress the direct representatives of the American people, but Congress also has the ability to change the mandate of the Federal Reserve through amending the Federal Reserve Act. Moreover, it was Congress that delegated its constitutional authority to "coin money" and "regulate the value thereof" to the Federal Reserve. 48

\footnotetext{
${ }^{46}$ This implies that a central bank has instrument independence, not goal independence, as distinguished by Debelle and Fischer (1994) and discussed in Meyer (2000).

${ }^{47}$ Numerical goals, however, are not always easy to define. For example, Judd and Rudebusch (1999) and Meyer (2000) point out that defining full employment is difficult since there is no consensus on an unemployment rate that corresponds to full employment. In addition, full employment is not a constant but varies as a result of demographics and government policies.

${ }^{48}$ See Article 1, Section 8, Clause 5 of the Constitution of the United States.
}

Indeed, in 1977 Congress amended the Federal Reserve Act to list the goals of the Federal Reserve and to require the Board of Governors to consult with Congress twice per year. This occurs through the Chairman's testimony before the Senate Banking, Housing, and Urban Affairs Committee and the House Banking and Financial Services Committee. The following year Congress further amended the Federal Reserve Act to require the Board of Governors to submit a written report to Congress prior to the Chairman's appearance before the congressional committees. This report had to include three things: (i) an analysis of recent economic conditions, (ii) the FOMC's forecast of economic conditions and monetary and credit aggregates, and (iii) the relationship between this forecast and the administration's forecast. The Federal Reports Elimination and Sunset Act of 1995 terminated the legal requirement for these semiannual reports and testimony at the end of 1999. Nevertheless, the FOMC decided to continue the reports and testimony as it believed they "enhanced its accountability to the public and the Congress" (FOMC, 1999).

In December 2000 Congress amended the Federal Reserve Act, reinstating the reporting requirement. Section 2B now specifies that "the Chairman of the Board shall appear before the Congress at semi-annual hearings" and that the Board shall submit a written report. The report is to contain
A discussion of the conduct of monetary policy and economic developments and prospects for the future, taking into account past and prospective developments in employment, unemployment, production, investment, real income, productivity, exchange rates, international trade and payments, and prices. (Section 2B (b))

Within the euro area, it is more difficult to answer the "accountable to whom" question. The European Parliament is a good candidate since it represents the European public. As stated by PadoaSchioppa (2000), a member of the Executive Board,

In the political order of the European Union, the only institution that directly derives its role and legitimacy from the citizens is the European Parliament...The European Parliament is the institution of Europe's democratically elected representatives, which represents the interests of the peoples of Europe. 
Yet, unlike the relationship between the U.S. Congress and the Federal Reserve, the European Parliament has little authority over the ECB. The European Parliament may request that members of the Executive Board appear before its committees, but has no such power over the other members of the Governing Council (the governors of the national central banks). ${ }^{49}$ Parliament gives advice on the appointments to the Executive Board but has no veto power over these, unlike the role of the U.S. Senate. ${ }^{50}$ Furthermore, Parliament has no power to change the laws governing the ECB. Indeed, the only way to change the mandate of the ECB or most other regulations regarding its operation is through an amendment to the treaty. This requires the agreement of all 15 governments of the European Union and then ratification of the amendments by the 15 national parliaments. In some countries passage of a public referendum is also necessary. Furthermore, the ECB must be consulted before any changes can be made to its charter.

The Maastricht Treaty does require the ECB to report annually "on the monetary policy of both the previous and current year" (Article 113) to the European Parliament, ECOFIN, the European Commission, and the European Council. The president of the ECB must present the report to the European Parliament and to ECOFIN. This requirement to report to multiple bodies reflects the lack of a single institution that has control over the mandate of the central bank and represents the European public.

\section{Transparency}

Transparency in monetary policy includes three key aspects: (i) transparency in goals, (ii) transparency in policy decisions, and (iii) transparency in the outlook. The first requires not only that the goals of the central bank be clearly defined but that they be easily understood. ${ }^{51}$ The Maastricht Treaty clearly identifies the goal of the ECB - price stability. The Governing Council further clarified this goal by giving a quantitative definition to price stability.

\footnotetext{
${ }^{49}$ Currently, once per quarter the ECB President appears before the European Parliament Committee of Economic and Monetary Affairs to explain the recent policy decisions of the Governing Council.

50 The U.S. Senate has no input into the appointments of the presidents of the District Banks nor does the European Parliament have any input into the appointments of the heads of the national central banks. On the FOMC, members of the Board of Governors outnumber the presidents; on the Governing Council, the governors of the national central banks outnumber the members of the Executive Board.

${ }^{51}$ See Judd and Rudebusch (1999).
}

Since deviations from price stability at a point in time are not necessarily indicators of a failure of policy, the ECB also sets a monetary aggregate target as a way to determine whether its policies are likely to be successful.

The goals of the Federal Reserve are stated in the Federal Reserve Act; but, as noted here previously, these goals are neither defined nor ranked. The FOMC was required to set monetary aggregate targets by the Federal Reserve Act; when this requirement expired at the end of 1999, however, it abandoned the practice.

Transparency also requires that policy decisions be communicated to the public in a clear way along with the reasoning behind the decisions. The ECB issues a press release and the president of the ECB holds a news conference (also attended by the vice president) following the monetary policy meetings of the Governing Council. ${ }^{52}$ The press release announces any changes in the main refinancing, marginal lending, and deposit rates. At the press conference the President gives an overview of economic conditions and the outlook for the euro area to provide a framework for the policy decision. The ECB also publishes a monthly bulletin discussing any policy changes as well as economic conditions in the euro area. ${ }^{53}$

The Federal Reserve also issues a press release following each FOMC meeting, but does not hold a news conference. Perhaps, as a result, the press release is more detailed than that of the Governing Council. ${ }^{54}$ The press release begins with an announcement of any change in the federal funds rate target. It then provides a brief overview of economic conditions and the reason for any policy change. Since March 2002, the release has included the vote of the FOMC. If any member dissents from the approved policy action, the member is named and the preferred policy action is noted. The release also states any changes in the discount rates along with a list of Districts requesting the change.

A day or so following its next scheduled meeting, the FOMC releases the minutes of the previous

\footnotetext{
52 Prior to 2001, when the Governing Council met twice per month to formulate monetary policy, the press conference was held only after one of the monthly meetings.

53 The press releases, transcripts of the press conference, and bulletin are available at <www.ecb.int $>$

${ }^{54}$ See the boxed insert "Press Releases Following Meetings of the FOMC and the Governing Council" for a comparison of recent press releases by the two central banks.
} 


\section{PRESS RELEASES FOLLOWING POLICY MEETINGS OF THE FOMC AND GOVERNING COUNCIL}

\section{Federal Reserve Press Release}

\section{Release Date: September 24, 2002 For immediate release}

The Federal Open Market Committee decided today to keep its target for the federal funds rate unchanged at $13 / 4$ percent.

The information that has become available since the last meeting of the Committee suggests that aggregate demand is growing at a moderate pace.

Over time, the current accommodative stance of monetary policy, coupled with still robust underlying growth in productivity, should be sufficient to foster an improving business climate. However, considerable uncertainty persists about the extent and timing of the expected pickup in production and employment owing in part to the emergence of heightened geopolitical risks.

Consequently, the Committee believes that, for the foreseeable future, against the background of its long-run goals of price stability and sustainable economic growth and of the information currently available, the risks are weighted mainly toward conditions that may generate economic weakness.

Voting for the FOMC monetary policy action were: Alan Greenspan, Chairman; William J. McDonough, Vice Chairman; Ben S. Bernanke; Susan S. Bies; Roger W. Ferguson, Jr.; Jerry L. Jordan; Donald L. Kohn; Mark W. Olson; Anthony M. Santomero, and Gary H. Stern.

Voting against the action were: Edward M. Gramlich and Robert D. McTeer, Jr.

Governor Gramlich and President McTeer preferred a reduction in the target for the federal funds rate.

\section{ECB Press Release}

\section{Monetary policy decisions 12 September 2002}

At today's meeting the Governing Council of the ECB decided that the minimum bid rate on the main refinancing operations and the interest rates on the marginal lending facility and the deposit facility will remain unchanged at $3.25 \%, 4.25 \%$ and $2.25 \%$ respectively.

The President of the ECB will comment on the considerations underlying these decisions at a press conference starting at 2.30 p.m. today.

meeting. ${ }^{55}$ The minutes provide a more detailed summary of the economic conditions, outlook, and reasons underlying the policy stance adopted at the meeting. The minutes do not ascribe policy views to any particular member of the FOMC except in the case of a dissenting vote.

The ECB does not release minutes of its meetings

\footnotetext{
${ }^{55}$ The press release and minutes are available at $<$ www.federalreserve gov/fomc >
}

nor are there formal votes. Every year the European Parliament has passed a resolution calling on the ECB to publish the minutes of Governing Council meetings. Members of the Governing Council argue that releasing minutes would limit the exchange of ideas that occur at the meeting and furthermore that the press conference already provides a summary of the meeting. ${ }^{56}$ The European Parliament has

${ }^{56}$ See, for example, Hämäläinen (2000). 
also called on the Governing Council to vote and to include in the minutes a summary of the vote without listing names. Duisenberg (2002) has argued that listing the dissenting views even anonymously "could lead to undue pressure on national central bank governors to deviate from a euro area perspective."

Transparency in policy also extends to the outlook for the economy. Understanding the central bank's outlook for the economy provides a guide to future policy moves. The Federal Reserve releases two types of information regarding its outlook for the economy. In its semiannual report to Congress it publishes the range and central tendency of the individual forecasts of the members of the Board of Governors and the presidents of the District Banks with respect to output, inflation, and unemployment for the current and following year. Since February 2000 the press release issued by the FOMC includes a balance of risks statement that indicates

how the Committee assesses the risks of heightened inflation pressures or economic weakness in the foreseeable future. This time frame in the new language is intended to cover an interval extending beyond the next FOMC meeting. (Federal Reserve Press Release, January 19, 2000)

The balance of risks statement (particularly shifts in the balance) is viewed as an indicator of future policy by the FOMC. 57

The ECB initially resisted publishing forecasts, but began including them in its Monthly Bulletin in December 2000. Neither the Federal Reserve nor the ECB publishes detailed forecasts like the staff forecasts of the Board of Governors.

\section{CONCLUSION}

Central banking is often described as an art, not a science. As a result there is no blueprint for the structure and operations of a central bank. Although the structures of the Federal Reserve System and the Eurosystem are similar, there are many differences in the way they operate. The Eurosystem is more decentralized than the Federal Reserve, with more tasks left to the national central banks. Even the conduct of monetary policy is more decentralized. Open market operations in the United States are conducted only by the Federal Reserve Bank of New York, following discussion between the staff at

${ }^{57}$ See Rasche and Thornton (2002). the Open Market Desk and at the Board of Governors. In the Eurosystem each national central bank carries out open market operations, although these are coordinated with the ECB.

The Board of Governors has more control over the appointments of the presidents of the District Banks than the Executive Board has over appointments of the heads of the national central banks. In the United States, the District Bank presidents must be approved by the Board of Governors. In Europe the national governments alone determine the heads of the national central banks.

Of course, the structure of central banks is not static. Over its 90-year history, the legislation governing the Federal Reserve has been amended numerous times. Although the laws governing the Eurosystem are more cumbersome to amend, if it follows the path of the Federal Reserve then centralization will increase over time.

Transparency has also increased. Not so many years ago monetary policy was shrouded in secrecy. Central banks seemed to make every effort to prevent monetary policy from being comprehensible to the general public. Initially, measures aimed at greater transparency were often imposed upon central banks. Perhaps surprising, central banks themselves have become champions of transparency, for transparency not only has proved to be helpful in making central banks more accountable but also has had the added benefits of increasing the credibility and predictability of monetary policy. As put by William Poole (2001), president of the Federal Reserve Bank of St. Louis, "we expect better public policy outcomes from a transparent process."

Disagreements remain over how to best make policy transparent while at the same time preserving the independence of the central banks. The Federal Reserve, for example, has recently begun publishing the roll call on the policy directive immediately following an FOMC meeting. If there is a dissent the action preferred by the dissenter(s) is also given. The ECB not only does not publish the vote, but also does not have a formal vote on policy at the Governing Council meetings. It is concerned that, given the multinational character of the Eurosystem, any knowledge of voting would lead to political pressure on the representatives of the national central banks. Over time, as the credibility and independence of the Eurosystem becomes established, it is likely that such concerns will fade. 


\section{REFERENCES}

Arestis, Philip; McCauley, Kevin and Sawyer, Malcolm. "From Common Market to EMU: A Historical Perspective of European Economic and Monetary Integration." Working Paper No. 263, Jerome Levy Economics Institute, February 1999.

Board of Governors of the Federal Reserve System. "The Federal Reserve System: Purposes and Functions." Washington, DC: 1994.

(Law Library). Textual Changes in the Federal Reserve Act and Related Laws, as of 1 June 2000.

Bordo, Michael D. and Jonung, Lars. "The Future of EMU: What Does the History of Monetary Unions Tell Us?" Working Paper No. 7365, NBER, September 1999.

Broz, J. Lawrence. "The Origins of Central Banking: Solutions to the Free-Rider Problem." International Organization, Spring 1998, 52(2), pp. 231-68.

Debelle, Guy and Fischer, Stanley. "How Independent Should a Central Bank Be?” Discussion Paper Series No. 392, Stanford University Center for Economic Policy Research, March 1994.

Duisenberg, Willem F. “ECB Press Conference.” 13 October 1998. < www.ecb.int/key/st981013.htm > .

"ECB Press Conference." 8 November 2001. $<$ www.ecb.int/key/01/sp011108_1.htm > .

Presentation of the ECB's Annual Report 2001 to the European Parliament. Strasbourg, 2 July 2002. <www.ecb.int/key/02/sp020702.htm > .

European Central Bank. "Memorandum of Understanding on Cooperation Between Payment Systems Overseers and Banking Supervisors in Stage Three of Economic and Monetary Union." European Central Bank Press Release, 2 April 2001a. <www.ecb.int/press/01/pr010402.pdf > .

The Role of Central Banks in Prudential Supervision. March 2001b. < www.ecb.int/pub/pdf/ prudentialsupcbrole_en.pdf $>$.

The European Central Bank. March 2001c. $<$ www.ecb.int/pub/pdf/ecbbren.pdf $>$.

The Single Monetary Policy in the Euro Area.

Frankfurt: European Central Bank, April 2002.

$<$ www.ecb.int/pub/pdf/gendoc2002en.pdf > .
European Communities. Institutions of the European Union. 1995-2002. < europa.eu.int/inst-en.htm\#1 > .

Consolidated Version of the Treaty Establishing

The European Community. < europa.eu.int/eur-lex/en/ treaties/dat/ec_cons_treaty_en.pdf > .

Protocol (No. 18) on the Statute of the European System of Central Banks and of the European Central Bank. <www.ecb.int/about/statescb.htm > .

European Parliament. "European Parliament Fact Sheets." Luxembourg: European Parliament, Directorate-General for Research, 2001. < www.europarl.eu.int/facts/ default.htm > .

Federal Open Market Committee. Minutes from 2-3 February 1999. <www.federalreserve.gov/fomc/minutes/ 19990202.htm >.

Federal Reserve Bank of Minneapolis. "The Districts Take Shape." The Region, August 1988.

Ferguson, Roger W. Jr. "Transparency in Central Banking: Rationale and Recent Developments." Remarks before the National Economists Club and Society of Government Economists, Washington, DC, 19 April 2001. < www. federalreserve.gov/boarddocs/speeches/2001/20010419/ default.htm $>$.

Greenspan, Alan. Opening remarks in "Achieving Price Stability," a symposium sponsored by the Federal Reserve Bank of Kansas City, Jackson Hole, Wyoming, 29-31 August 1996, pp. 1-5. <www.kc.frb.org/PUBLICAT/ SYMPOS/1996/pdf/s96green.pdf > .

Hammes, David. "Locating Federal Reserve Districts and Headquarters Cities." Federal Reserve Bank of Minneapolis The Region, September 2001, 15(3), pp. 24-27, 55-65.

Hämäläinen, Sirkka. "The Single Monetary PolicyFormulation, Implementation and Communication." Presented at the 32nd Annual Conference of the Money, Macro and Finance Research Group, South Bank University, London, 8 September 2000. < www.ecb.int/ key/00/sp000908_1.htm > .

Haring, Norbert and Barber, Tony. "How the ECB Works." Financial Times, 19 December 2001 (updated February 8, 2002). < specials.ft.com/euro/ecbback/FT34O19FFVC. html > .

International Monetary Fund. World Economic Outlook: 
Recessions and Recoveries. Washington, DC: International Monetary Fund, April 2002. < www.imf.org/external/pubs/ $\mathrm{ft} / \mathrm{weo} / 2002 / 01>$.

Judd, John P. and Rudebusch, Glenn D. "The Goals of U.S. Monetary Policy." Federal Reserve Bank of San Francisco Economic Letter, 99-04, 29 January 1999.

$<$ www.frbsf.org/econrsrch/wklyltr/wklyltr99/el99-04. html $>$.

King, Mervyn. "How Should Central Banks Reduce Inflation?-Conceptual Issues" in "Achieving Price Stability," a symposium sponsored by the Federal Reserve Bank of Kansas City, Jackson Hole, Wyoming, 29-31 August 1996, pp. 53-91. <www.kc.frb.org/PUBLICAT/ SYMPOS/1996/pdf/s96king.pdf > .

Madigan, Brian F. and Nelson, William R. "Proposed Revision to the Federal Reserve's Discount Window Lending Programs." Federal Reserve Bulletin, July 2002, 88(7), pp. 313-19.

Meulendyke, Ann-Marie. United States Monetary Policy and Financial Markets. Federal Reserve Bank of New York, 1998.

Meyer, Laurence H. "Come with Me to the FOMC." Gillis Lecture, Willamette University, Salem, Oregon, 2 April 1998. < www.federalreserve.gov/boarddocs/speeches/ 1998/199804022.htm > .

. "The Politics of Monetary Policy: Balancing Independence and Accountability." Remarks at the University of Wisconsin, LaCrosse, Wisconsin, 24 October 2000. < www.federalreserve.gov/boarddocs/speeches/ 2000/20001024.htm >

"Payment of Interest on Reserves." Testimony before the Financial Services Subcommittee on Financial Institutions and Consumer Credit, U.S. House of Representatives, 13 March 2001. <www.federalreserve. gov/boarddocs/testimony/2001/20010313/default.htm > .

Nash, Betty Joyce. "The Federal Open Market Committee: Data and Intuition Meet." Federal Reserve Bank of Richmond Region Focus, Summer 2002, 6(2/3). < www. rich.frb.org/pubs/regionfocus/summer02/fomc.html > .
Padoa-Schioppa, Tommaso. "EMU and Banking Supervision." Speech at the London School of Economics, Financial Markets Group, 24 February 1999. < www.ecb.int/key/ sp990224.htm > .

"An Institutional Glossary of the Eurosystem." Presented at the conference, "The Constitution of the Eurosystem: The Vies of the EP and the ECB," 8 March 2000. < www.ecb.int/key/00/sp000308_1.htm > .

Pollard, Patricia S. "Central Bank Independence and Economic Performance." Federal Reserve Bank of St. Louis Review, July/August 1993, 75(4), pp. 21-36.

"EMU: Will It Fly?" Federal Reserve Bank of St. Louis Review, July/August 1995, 77(4), pp. 3-16.

Poole, William. "Communicating the Stance of Monetary Policy." Speech at the University of Missouri, Columbia, 4 November 1999. <www.stlouisfed.org/news/speeches/ 1999/11_04_99.html > .

"Central Bank Transparency: Why and How?" Presented at the Federal Reserve Bank of Philadelphia Policy Forum, 30 November 2001. <www.stlouisfed.org/ news/speeches/2001/11_30_01.html >.

Prati, Alessandro and Schinasi, Garry J. "Ensuring Financial Stability in the Euro Area." Finance and Development, December 1998, 35(4), pp. 12-15.

Primm, James Neal. A Foregone Conclusion: The Founding of the Federal Reserve Bank of St. Louis. St. Louis: Federal Reserve Bank of St. Louis, 1989. < www.stlouisfed.org/ publications/foregone $>$.

Pringle, Robert, ed. The Morgan Stanley Dean Witter Central Bank Directory 2002. London: Central Banking Publications, 2002.

Rasche, Robert H. and Thornton, Daniel L. “The FOMC's Balance-of-Risks Statement and Market Expectations of Policy Actions." Federal Reserve Bank of St. Louis Review, September/October 2002, 84(5), pp. 37-50.

Wellnik, A.H.E.M. "European Economic and Monetary Cooperation from an Historical Perspective." BIS Review, 16 April 1997 